\title{
SEED SIZE AND QUANTITATIVE CHARACTERS IN AVENA BARBATA
}

\author{
ELMARIE S. HUTCHINSON \\ Department of Genetics, University of California, Davis, California 95616, USA \\ Received 7.vii.83
}

\begin{abstract}
SUMMARY
Seed-size differences in Avena barbata Pott ex Link are of two sorts. First, there is a seed-size dimorphism (floret position) such that half of the seeds on every plant are larger. Second, the characteristic seed sizes of certain populations are significantly larger than those of other populations. This study reports relationships between seed size and quantitative characters at very early, intermediate, and late stages of the plant's life cycle: young seedlings of Avena barbata grown from smaller seeds are smaller than seedlings grown from larger seeds. Larger seeds do not produce plants that are larger at later stages if the seed-size difference is determined by floret position within the same genotype. Larger seeds do produce plants that are larger at later stages if the seed-size difference characterizes populations having different genotypes at many loci.
\end{abstract}

\section{INTRODUCTION}

That larger seeds produce larger seedlings than do smaller seeds of the same species (or variety) is a truism. The need to improve seedling establishment of perennial grass species sown for forage has motivated many studies (e.g., Kneebone and Cremer, 1955) on the relationship between seed size and seedling size and vigor. Only the seedling stage has generally been of concern in such studies of seed-size effects in grasses.

Implications about seed-size effects throughout the whole life cycle of the annual grass Avena barbata Pott ex Link (slender wild oat) are now of interest because of the way they may touch upon results from current ecological genetics investigations of the species.

What are commonly referred to as seeds of grasses are grains (caryopses). The actual seed-the embryo-is enclosed in the grain, surrounded by maternal contributions of foodstores. Within-species grain-size differences derive from variations in the maternal contribution and not from varying embryo sizes. The grain together with its outer coverings is a floret. The inflorescence of $A$. barbata is a loose panicle bearing spikelets, each of which contains an upper floret and a lower floret. Following convention, I refer to differences in floret size as "seed-size differences" throughout this report.

Seed-size differences in $A$. barbata are of two sorts. The first relates to the morphology of the inflorescence: In each spikelet the upper floret is smaller (contains a smaller grain) and the lower, larger. Although different in size, the pair of "seeds" in a spikelet have identical genotypes at many of their loci (as, indeed, do all of the "seeds" of a particular maternal plant) because in this species most seeds result from self-fertilisation. The seed-size dimorphism may contribute to $A$. barbata's success as a colonizer: there 
is reasonable speculation that such variation may enable an individual to establish descendants under a wider range of conditions than can one with invariant seeds (Cavers and Harper, 1966).

In addition to the seed-size difference related to floret position, there are striking differences between certain California populations of $\boldsymbol{A}$. barbata for spikelet and floret size.

Evaluation of how seed-size variation in the species relates to variation in certain other quantitative characters is needed because these quantitative characters are being used to increase our knowledge of genetic differences among California populations of the species (Hamrick and Allard, 1975; Hutchinson and Allard, in preparation). If, for example, a plant grown from an upper floret seed is shorter at maturity than a plant grown from a lower floret seed of the same genotype, studies of between-population quantitative variation must include data on floret position of the seeds producing the experimental plants. One published study on a grass species suggests that a seed-size effect upon size of mature plant is not likely: Harkness (1965) found that in Italian ryegrass seed-size effects prevailed only during the first few weeks of growth.

A study addressed to two questions is reported here. First, as expected from demonstrations with many other plant species, are young $\boldsymbol{A}$. barbata seedlings grown from larger seeds larger than those grown from smaller seeds? Second, is there any effect of seed size upon quantitative characters at later stages?

\section{MAterials AND METHOdS}

The seed collections, electrophoretic survey, and common gardens for this study were also used for a larger study of genetic markers and ecotypic differentiation in A. barbata, details of which will be reported elsewhere (Hutchinson and Allard, in preparation).

Natural populations of $\boldsymbol{A}$. barbata at six sites in California supplied seeds for the study of seed-size effects. Panicles collected from 50-100 different plants in each population were kept separate so that as many different plants as possible would contribute seeds to each part of the study. Spikelets were selected at random from these panicles; the upper and lower florets were separated to give an upper-floret sample and a lower-floret sample from each population. Forty florets from each of these separated samples were weighed together for calculation of mean floret weights for each population. Table 1 gives the locations of the sampled populations and their mean upper- and lower-floret weights.

The last row in table 1 presents, in coded form, the characteristic multilocus genotype of each population. The loci govern several enzymes and two morphological characters. The first six digits in the code specify enzyme genotypes, revealed by electrophoresis, at six pairs of presumably duplicated loci. ( $A$. barbata is a diploidised tetraploid.) The last two digits code for color of lemma (part of the outer covering of the seed) and presence or absence of leaf-and-leaf-sheath pubescence. The San Ardo (SA), Sierra Foothill Range (FR), Del Loma (DL), and Calistoga Horse Pasture (HP) population samples were virtually monomorphic for their respective multilocus genotypes. The Geyserville (GE) population sample was so polymorphic at three of the pairs of enzyme loci that characteristic genotypes could 
TABLE 1

Locations in California supplying seeds and characterisation of their A. barbata plants

\begin{tabular}{|c|c|c|c|c|c|c|}
\hline Item & $\begin{array}{c}\text { San } \\
\text { Ardo }\end{array}$ & $\begin{array}{c}\text { Sierra } \\
\text { Foothill } \\
\text { Range }\end{array}$ & $\begin{array}{c}\text { Del } \\
\text { Loma }\end{array}$ & $\begin{array}{c}\text { Calistoga } \\
\text { horse } \\
\text { pasture }\end{array}$ & $\begin{array}{l}\text { Geyser- } \\
\text { ville }\end{array}$ & Marshall \\
\hline Abbreviation & SA & FR & DL & HP & $\mathrm{GE}$ & MA \\
\hline County & Monterey & Yuba & Trinity & Napa & Sonoma & Marin \\
\hline Latitude (N) & $36^{\circ} 00^{\prime}$ & $30^{\circ} 15^{\prime}$ & $40^{\circ} 47^{\prime}$ & $38^{\circ} 35^{\prime}$ & $38^{\circ} 42 \cdot 5^{\prime}$ & $38^{\circ} 10 \cdot 5^{\prime}$ \\
\hline Longitude (W) & $120^{\circ} 55 \cdot 5^{\prime}$ & $121^{\circ} 17 \cdot 5^{\prime}$ & $123^{\circ} 20^{\prime}$ & $122^{\circ} 34^{\prime}$ & $122^{\circ} 53^{\prime}$ & $122^{\circ} 54^{\prime}$ \\
\hline Elevation, $\mathrm{m}$ & 207 & 335 & 366 & 110 & 67 & 12 \\
\hline \multicolumn{7}{|l|}{ Mean weight, mg } \\
\hline upper floret & $5 \cdot 8$ & $5 \cdot 6$ & 4.8 & $10 \cdot 3$ & $9 \cdot 2$ & $9 \cdot 5$ \\
\hline lower floret & 8.7 & 8.7 & $7 \cdot 8$ & $15 \cdot 5$ & $14 \cdot 4$ & $13 \cdot 7$ \\
\hline Coded genotype & 11111111 & 11111111 & 11111111 & 22222122 & $1-3222$ & 21222222 \\
\hline
\end{tabular}

not be specified (as indicated by dashes in the code). The Marshall (MA) population sample was polymorphic at all eight of the pairs of loci but the most common genotype at each was apparent. Notice that the SA, FR, and DL populations are all characterized by the same multilocus genotype. This genotype corresponds to a five-locus genotype characterizing several $\boldsymbol{A}$. barbata populations previously studied (as reported by Allard et al., 1972; Clegg and Allard, 1972; Hamrick and Allard, 1972; and Hamrick and Holden, 1979); this five-locus genotype was labeled the "xeric genotype" by Hamrick and Allard (1972) because samples taken from the sites and subsites judged to be the most xeric were monomorphic for it. The five-locus "mesic genotype" of these studies corresponds to the multilocus genotype of the HP population in my study.

These multilocus genotypes mark additional genetic differences between populations, as has been ascertained by population studies of quantitative characters (Hamrick and Allard, 1975; Hutchinson and Allard, in preparation). The multilocus genotypes thus provide information for hypotheses about between-population differences in seed size and seed-size effects. That is, SA, FR, and DL samples of the same floret position are expected to be highly similar for seed and seedling size. HP, GE, and MA samples of the same floret position are likely to differ in seed and seedling size from each other and from SA, FR, and DL samples of the same floret position.

\section{(i) Seedling common-garden study}

Four flats containing nutrient-free soil $\left(1 \mathrm{ft}^{3}\right.$ peat: $1 \mathrm{ft}^{3}$ sand: $151 \mathrm{~g}$ dolomite) were sown as four replicates. A row of 20 florets from each upper- and lower-floret sample from each population was sown in each flat. Samples were assigned to the twelve rows in each flat at random.

The flats were kept in a controlled-temperature chamber maintained at $22^{\circ} \mathrm{C}$ for 15 -hour days alternating with $17^{\circ} \mathrm{C}$ for 9 -hour nights. Only distilled water was applied to the flats.

The seedlings were harvested 23 days after sowing. Whether each seedling had one or two leaves at the time of harvest was recorded. The length of the longest leaf of each seedling was measured in centimeters. The leaf 
area, in square centimeters, of each was measured with an electronic leaf-area scanner. The seedlings were dried in a $55^{\circ} \mathrm{C}$ oven for 72 hours; each was then weighed to the nearest tenth of a milligram.

\section{(ii) Mature-plant common-garden study}

Gardens were sown at two University of California field stations at grassland sites where $A$. barbata is indigenous in order to observe experimental plants going through their life cycle under natural conditions. Seeds were sown in the fall to germinate with the first wetting rains. Thereafter the plants were undisturbed except for being measured. Neither water nor nutrients were applied at any stage; the other annual plants in the gardens, growing from seeds in the soil, were also left undisturbed. The garden producing the SFRFS 1979 results was sown in the fall of 1978 at the Sierra Foothill Range Field Station, which is in the northern end of the Sierra Nevada (Yuba County; $39^{\circ} 15^{\prime} \mathrm{N} ; 121^{\circ} 17 \cdot 5^{\prime} \mathrm{W}$; elev, $335 \mathrm{~m}$ ). The garden producing the Hopland 1980 results was sown in the fall of 1979 at the Hopland Field Station, which is in the Inner Coast Ranges (Mendocino County; $39^{\circ} 00 \cdot 5^{\prime} \mathrm{N} ; 123^{\circ} 05^{\prime} \mathrm{W}$; elev, $335 \mathrm{~m}$ ).

The layout of the gardens- -64 plots, each one meter on a side, containing 16 plants arranged in a grid-was designed principally for a larger betweenpopulation study of $A$. barbata. Four places in each plot were reserved for an upper and a lower floret from each of two populations. Places in plots were assigned at random. In 1978, florets from the DL and HP populations were sown, and in 1979, from FR and HP.

In mid-April of each study year, I counted and recorded the number of juvenile tillers of each experimental plant. (A juvenile tiller of a grass plant is a shoot having the potential to flower; whether it does depends on the environment.) I recorded the date on which each plant flowered (i.e., the top floret of the first tiller emerged) and measured the length and width of the flagleaf of the first tiller. At the end of the life cycle, I recorded the number of spikelets on each plant and multiplied this by two to get the number of seeds. I weighed the aerial portion of each plant after all florets had been shed and the remains had been oven-dried.

\section{(iii) Statistical analysis}

For both the seedling and the mature-plant study, $t$-tests were calculated to compare differences between pairs of means. $t$-tests were the statistic of choice for several reasons, including the facts that they are exact where group sizes are unequal and they may be evaluated by separate variance estimates where variances of the means are heterogeneous. Testing for heterogeneity of means was done, and separate variance estimates were used where appropriate. In nearly all instances, I evaluated the $t$-tests as one-tailed tests because appropriate alternative hypotheses could be formulated using results from previous work. For example, for all comparisons of upper-and lower-floret samples from the same population, the alternative hypothesis was that the lower-floret mean was greater than the upper-floret mean. The exceptions that were evaluated as two-tailed tests were comparisons of DL and FR means and between-population comparisons of flowering-date means. 


\section{Results}

\section{(i) Seedling study}

Table 2 gives the sample sizes, means, and standard errors for the four characters measured on each seedling. The results of $t$-tests comparing pairs of these means are summarised in table 3. For each of the four characters in every one of the populations, the mean of the lower-floret sample was significantly greater, at the 0.01 probability level, than that of the upperfloret sample. For each character, HP means were significantly greater than FR and DL means. No significant difference was found between means of FR and DL lower-floret samples for any character, and none between FR and DL upper-floret sample means except for the leaf area pair of means, which were significantly different $(P=0 \cdot 01)$.

TABLE 2

Means of measurements made on seedlings grown from population samples of separated upper and lower florets

\begin{tabular}{|c|c|c|c|c|c|}
\hline $\begin{array}{c}\text { Seedling } \\
\text { sample }\end{array}$ & $n$ & $\begin{array}{c}\text { Number } \\
\text { of } \\
\text { leaves, in } \mathrm{cm}\end{array}$ & $\begin{array}{c}\text { Length of } \\
\text { longest } \\
\text { leaves, in } \mathrm{cm}\end{array}$ & $\begin{array}{c}\text { Leaf } \\
\text { area, } \\
\text { in sq } \mathbf{m g}\end{array}$ & $\begin{array}{c}\text { Dry } \\
\text { weight, } \\
\text { in mg }\end{array}$ \\
\hline \multicolumn{6}{|l|}{ Upper floret } \\
\hline SA & 63 & $\begin{array}{l}1 \cdot 5 \\
(0.063) \dagger\end{array}$ & $\begin{array}{c}10.66 \\
(0.267)\end{array}$ & $\begin{array}{c}1.055 \\
(0.059)\end{array}$ & $\begin{array}{c}1.37 \\
(0 \cdot 124)\end{array}$ \\
\hline FR & 67 & $\begin{array}{l}1.4 \\
(0.061)\end{array}$ & $\begin{array}{l}10 \cdot 36 \\
(0.366)\end{array}$ & $\begin{array}{c}1.060 \\
(0.065)\end{array}$ & $\begin{array}{l}1.52 \\
(0.135)\end{array}$ \\
\hline DL & 70 & $\begin{array}{l}1.3 \\
(0.057)\end{array}$ & $\begin{array}{l}9.99 \\
(0.260)\end{array}$ & $\begin{array}{c}0.792 \\
(0.041)\end{array}$ & $\begin{array}{c}1.36 \\
(0.099)\end{array}$ \\
\hline HP & 71 & $\begin{array}{c}1.8 \\
(0.043)\end{array}$ & $\begin{array}{l}13.81 \\
(0.192)\end{array}$ & $\begin{array}{c}1.839 \\
(0.075)\end{array}$ & $\begin{array}{c}3.53 \\
(0.132)\end{array}$ \\
\hline GE & 66 & $\begin{array}{l}1.8 \\
(0.046)\end{array}$ & $\begin{array}{l}15 \cdot 20 \\
(0.423)\end{array}$ & $\begin{array}{c}2.412 \\
(0.168)\end{array}$ & $\begin{array}{c}4 \cdot 19 \\
(0 \cdot 307)\end{array}$ \\
\hline MA & 75 & $\begin{array}{l}1.7 \\
(0.055)\end{array}$ & $\begin{array}{l}13 \cdot 17 \\
(0.400)\end{array}$ & $\begin{array}{c}1.671 \\
(0.106)\end{array}$ & $\begin{array}{c}2 \cdot 79 \\
(0.198)\end{array}$ \\
\hline \multicolumn{6}{|l|}{ Lower floret } \\
\hline SA & 69 & $\begin{array}{l}1.9 \\
(0.043)\end{array}$ & $\begin{array}{l}12 \cdot 42 \\
(0 \cdot 218)\end{array}$ & $\begin{array}{c}1.601 \\
(0.067)\end{array}$ & $\begin{array}{c}2 \cdot 37 \\
(0 \cdot 145)\end{array}$ \\
\hline FR & 69 & $\begin{array}{l}1.6 \\
(0.059)\end{array}$ & $\begin{array}{l}12 \cdot 17 \\
(0.334)\end{array}$ & $\begin{array}{c}1.493 \\
(0.080)\end{array}$ & $\begin{array}{c}2 \cdot 71 \\
(0 \cdot 156)\end{array}$ \\
\hline DL & 71 & $\begin{array}{l}1.6 \\
(0.057)\end{array}$ & $\begin{array}{l}11 \cdot 80 \\
(0.294)\end{array}$ & $\begin{array}{c}1.331 \\
(0.076)\end{array}$ & $\begin{array}{c}2 \cdot 50 \\
(0 \cdot 164)\end{array}$ \\
\hline HP & 78 & $\begin{array}{l}2 \cdot 0 \\
(0.013)\end{array}$ & $\begin{array}{l}15 \cdot 60 \\
(0 \cdot 221)\end{array}$ & $\begin{array}{c}2 \cdot 640 \\
(0.104)\end{array}$ & $\begin{array}{c}5 \cdot 40 \\
(0.218)\end{array}$ \\
\hline $\mathrm{GE}$ & 76 & $\begin{array}{l}2.0 \\
(0.018)\end{array}$ & $\begin{array}{l}17 \cdot 26 \\
(0 \cdot 284)\end{array}$ & $\begin{array}{c}3.444 \\
(0.136)\end{array}$ & $\begin{array}{c}6 \cdot 34 \\
(0 \cdot 263)\end{array}$ \\
\hline MA & 75 & $\begin{array}{l}1.9 \\
(0.029)\end{array}$ & $\begin{array}{l}16 \cdot 21 \\
(0.239)\end{array}$ & $\begin{array}{c}2.835 \\
(0.141)\end{array}$ & $\begin{array}{c}4 \cdot 65 \\
(0 \cdot 256)\end{array}$ \\
\hline
\end{tabular}

† Standard errors of the means are given in parentheses below the means.

\section{(ii) Mature-plant study}

Table 4 gives the sample sizes, means, and standard errors of the eight characters measured on each plant. Table 5 summarises the results of $t$-tests comparing-for each character in each garden-all possible pairs of these 
TABLE 3

Results from one-tailed t-tests comparing pairs of means of separate upper $\left({ }^{U}\right)$ and lower $\left.{ }^{L}\right)$ floret population samples measured as seedlings

\begin{tabular}{|c|c|c|c|c|c|c|c|c|}
\hline \multirow{2}{*}{$\begin{array}{l}\text { Pair of } \\
\text { seedling } \\
\text { samples }\end{array}$} & \multicolumn{2}{|c|}{$\begin{array}{c}\text { Number } \\
\text { of } \\
\text { leaves }\end{array}$} & \multicolumn{2}{|c|}{$\begin{array}{l}\text { Length of } \\
\text { longest } \\
\text { leaf, in } \mathrm{cm}\end{array}$} & \multicolumn{2}{|c|}{$\begin{array}{c}\text { Leaf } \\
\text { area, } \\
\text { in sq } \mathrm{cm}\end{array}$} & \multicolumn{2}{|c|}{$\begin{array}{c}\text { Dry } \\
\text { weight, } \\
\text { in mg }\end{array}$} \\
\hline & $t$ & $\mathrm{df}$ & $t$ & df & $t$ & df & $t$ & df \\
\hline $\begin{array}{l}S^{U}-S^{L} \\
F^{U}-F^{L} \\
D L^{U}-D^{L} \\
H P^{U}-H^{L} \\
G E^{U}-G^{L} \\
M^{U}-M^{L}\end{array}$ & $\begin{array}{l}4 \cdot 13^{* *} \\
2 \cdot 07^{* *} \\
3 \cdot 78^{* *} \\
3 \cdot 15^{* *} \\
2 \cdot 82^{* *} \\
4 \cdot 48^{* *}\end{array}$ & $\begin{array}{r}110 \\
134 \\
139 \\
82 \\
86 \\
112\end{array}$ & $\begin{array}{l}5 \cdot 15^{* *} \\
3 \cdot 66^{* *} \\
4 \cdot 62^{* *} \\
6 \cdot 08^{* *} \\
4 \cdot 05^{* *} \\
6 \cdot 52^{* *}\end{array}$ & $\begin{array}{l}130 \\
134 \\
139 \\
147 \\
116 \\
121\end{array}$ & $\begin{array}{l}6 \cdot 08^{* *} \\
4 \cdot 19^{* *} \\
6 \cdot 25^{* *} \\
6 \cdot 24^{* *} \\
4 \cdot 82^{* *} \\
6 \cdot 60^{* *}\end{array}$ & $\begin{array}{l}130 \\
134 \\
107 \\
137 \\
140 \\
148\end{array}$ & $\begin{array}{l}5 \cdot 18^{* *} \\
5 \cdot 77^{* *} \\
5 \cdot 94^{* *} \\
7 \cdot 31^{* *} \\
5 \cdot 36^{* *} \\
5 \cdot 75^{* *}\end{array}$ & $\begin{array}{l}130 \\
131 \\
115 \\
125 \\
140 \\
148\end{array}$ \\
\hline $\begin{array}{l}\mathrm{FR}^{\mathrm{U}}-\mathrm{HP}^{\mathrm{U}} \\
\mathrm{FR}^{\mathrm{U}}-\mathrm{HP}^{\mathrm{L}} \\
\mathrm{FR}^{\mathrm{L}}-\mathrm{HP}^{\mathrm{U}} \\
\mathrm{FR}^{\mathrm{L}} \mathrm{HP}^{\mathrm{L}}\end{array}$ & $\begin{array}{l}5 \cdot 30^{* *} \\
8 \cdot 63^{* *} \\
3 \cdot 05^{* *} \\
6 \cdot 05^{* *}\end{array}$ & $\begin{array}{r}120 \\
72 \\
138 \\
74\end{array}$ & $\begin{array}{r}8 \cdot 34^{* *} \\
12 \cdot 27^{* *} \\
4 \cdot 23^{* *} \\
8 \cdot 56^{* *}\end{array}$ & $\begin{array}{l}100 \\
110 \\
109 \\
120\end{array}$ & $\begin{array}{r}7 \cdot 84^{* *} \\
12 \cdot 86^{* *} \\
3 \cdot 16^{* *} \\
8 \cdot 72^{* *}\end{array}$ & $\begin{array}{l}136 \\
126 \\
138 \\
139\end{array}$ & $\begin{array}{r}10 \cdot 69^{* *} \\
15 \cdot 11^{* *} \\
4 \cdot 03^{* *} \\
10 \cdot 01^{* *}\end{array}$ & $\begin{array}{l}132 \\
125 \\
137 \\
136\end{array}$ \\
\hline $\begin{array}{l}\mathrm{DL}^{\mathrm{U}}-\mathrm{HP} \mathrm{P}^{\mathrm{U}} \\
\mathrm{DL}^{\mathrm{U}}-\mathrm{HP} \mathrm{P}^{\mathrm{L}} \\
\mathrm{DL}^{\mathrm{L}}-\mathrm{HP} \mathrm{P}^{\mathrm{U}} \\
\mathrm{DL}^{\mathrm{L}}-\mathrm{HP}^{\mathrm{L}}\end{array}$ & $\begin{array}{r}7 \cdot 02^{* *} \\
11 \cdot 00^{* *} \\
2 \cdot 75^{* *} \\
5 \cdot 80^{* *}\end{array}$ & $\begin{array}{r}139 \\
76 \\
140 \\
77\end{array}$ & $\begin{array}{r}11 \cdot 84^{* *} \\
16 \cdot 56^{* *} \\
5 \cdot 72^{* *} \\
10 \cdot 47^{* *}\end{array}$ & $\begin{array}{l}139 \\
146 \\
121 \\
147\end{array}$ & $\begin{array}{r}12 \cdot 30^{* *} \\
16 \cdot 49^{* *} \\
4 \cdot 77^{* *} \\
10 \cdot 14^{* *}\end{array}$ & $\begin{array}{l}108 \\
100 \\
140 \\
138\end{array}$ & $\begin{array}{r}13 \cdot 19^{* *} \\
16 \cdot 83^{* *} \\
4 \cdot 91^{* *} \\
10 \cdot 60^{* *}\end{array}$ & $\begin{array}{l}138 \\
107 \\
139 \\
140\end{array}$ \\
\hline $\begin{array}{l}\mathrm{FR}^{\mathrm{U}}-\mathrm{DL}^{\mathrm{U}} \\
\mathrm{FR}^{\mathrm{L}}-\mathrm{DL}^{\mathrm{L}}\end{array}$ & $\begin{aligned} & 1 \cdot 25^{\mathrm{NS}} \\
-0 \cdot 30^{\mathrm{NS}} & \end{aligned}$ & $\begin{array}{l}135 \\
138\end{array}$ & $\begin{array}{l}0 \cdot 84^{\text {NS }} \\
0 \cdot 84^{\text {NS }}\end{array}$ & $\begin{array}{l}120 \\
138\end{array}$ & $\begin{array}{l}3 \cdot 51^{* *} \\
1 \cdot 47^{N S}\end{array}$ & $\begin{array}{l}112 \\
138\end{array}$ & $\begin{array}{l}0.94^{\text {NS }} \\
0.94^{\text {NS }}\end{array}$ & $\begin{array}{l}132 \\
138\end{array}$ \\
\hline
\end{tabular}

** The difference between the pair of means is significant at the 0.01 probability level.

NS There is no significant difference between the means.

means. In the SFRFS 1979 garden there were no significant differences between the means of the upper and lower floret samples from the same population. This is also true of the Hopland 1980 means except for the HP pairs for number of juvenile tillers and width of flagleaf, which were significantly different at the 0.05 probability level, but not at the 0.01 level. In both gardens most of the between-population pairs of means differed significantly.

\section{Discussion}

Differences and similarities among sample means for seedling characters (table 3) were consistent with the differences and similarities in mean floret weights (table 1) and thus with the principle that larger seeds produce larger seedlings. The mean weight of upper florets in each population was only about two-thirds that of the lower florets from the same spikelets. For all four characters in all populations, the upper-floret seedlings had significantly smaller means than the lower-floret seedlings.

The mean lower-floret weights of the xeric-genotype populations (SA, FR, and DL) were less than the mean upper-floret weights of the other populations. As a sample of the between-population patterns in the seedling data, $t$-test results of comparisons between HP, FR, and DL means were given in table 3. This particular set of $t$-tests was included because these three populations contributed the seeds for the second stage of study, of 
TABLE 4

Sample sizes and means of measurements made on mature plants grown from population samples of separated upper and lower florets

\begin{tabular}{|c|c|c|c|c|c|c|c|c|c|}
\hline \multirow[b]{2}{*}{ Character } & \multirow[b]{2}{*}{ Garden } & \multicolumn{2}{|c|}{$\mathrm{DL}^{\mathrm{U}}$ or $\mathrm{FR}^{\mathrm{U} *}$} & \multicolumn{2}{|c|}{$\mathrm{DL}^{\mathrm{L}}$ or $\mathrm{FR}^{\mathrm{L} *}$} & \multicolumn{2}{|r|}{$\mathrm{HP}^{\mathrm{U}}$} & \multicolumn{2}{|c|}{$\mathrm{HP}^{\mathrm{L}}$} \\
\hline & & $n$ & $\overline{\boldsymbol{X}}$ & $n$ & $\overline{\boldsymbol{X}}$ & $n$ & $\overline{\boldsymbol{X}}$ & $n$ & $\overline{\boldsymbol{X}}$ \\
\hline Number of juvenile & SFRFS 1979 & 12 & $\begin{array}{l}5 \cdot 3 \\
(0.667) \dagger\end{array}$ & 24 & $\begin{array}{c}6.6 \\
(0.659)\end{array}$ & 7 & $\begin{array}{l}13.4 \\
(1.863)\end{array}$ & 30 & $\begin{array}{l}10.6 \\
(0.855)\end{array}$ \\
\hline tillers & Hopland 1980 & 42 & $\begin{array}{c}1 \cdot 3 \\
(0.077)\end{array}$ & 57 & $\begin{array}{l}1.4 \\
(0.083)\end{array}$ & 58 & $\begin{array}{l}1 \cdot 8 \\
(0 \cdot 142)\end{array}$ & 54 & $\begin{array}{l}2 \cdot 2 \\
(0 \cdot 173)\end{array}$ \\
\hline Length of flagleaf, & SFRFS 1979 & 13 & $\begin{array}{l}23 \cdot 3 \\
(2 \cdot 205)\end{array}$ & 23 & $\begin{array}{l}25 \cdot 6 \\
(1 \cdot 539)\end{array}$ & 5 & $\begin{array}{l}41 \cdot 8 \\
(4 \cdot 609)\end{array}$ & 29 & $\begin{array}{l}42.6 \\
(1.875)\end{array}$ \\
\hline in $\mathrm{mm}$ & Hopland 1980 & 39 & $\begin{array}{l}23.7 \\
(1.621)\end{array}$ & 55 & $\begin{array}{l}26.1 \\
(0.981)\end{array}$ & 56 & $\begin{array}{l}35 \cdot 2 \\
(1.962)\end{array}$ & 53 & $\begin{array}{l}38 \cdot 1 \\
(1.540)\end{array}$ \\
\hline Width of flagleaf, & SFRFS 1979 & 12 & $\begin{array}{l}2 \cdot 2 \\
(0 \cdot 168)\end{array}$ & 23 & $\begin{array}{l}2 \cdot 5 \\
(0.174)\end{array}$ & 5 & $\begin{array}{l}2.9 \\
(0.291)\end{array}$ & 29 & $\begin{array}{c}3 \cdot 1 \\
(0 \cdot 152)\end{array}$ \\
\hline in $\mathrm{mm}$ & Hopland 1980 & 39 & $\begin{array}{l}2.2 \\
(0 \cdot 128)\end{array}$ & 55 & $\begin{array}{l}2.2 \\
(0.081)\end{array}$ & 56 & $\begin{array}{l}2.7 \\
(0 \cdot 107)\end{array}$ & 53 & $\begin{array}{l}3.0 \\
(0 \cdot 121)\end{array}$ \\
\hline \multirow{2}{*}{$\begin{array}{l}\text { Number of } \\
\text { flowering } \\
\text { tillers }\end{array}$} & SFRFS 1979 & 13 & $\begin{array}{l}2.5 \\
(0.447)\end{array}$ & 23 & $\begin{array}{l}2.4 \\
(0.234)\end{array}$ & 5 & $\begin{array}{l}4 \cdot 4 \\
(0 \cdot 678)\end{array}$ & 29 & $\begin{array}{l}3.8 \\
(0.294)\end{array}$ \\
\hline & Hopland 1980 & 35 & $\begin{array}{l}1.5 \\
(0.085)\end{array}$ & 54 & $\begin{array}{l}1.4 \\
(0.073)\end{array}$ & 57 & $\begin{array}{c}1.2 \\
(0.049)\end{array}$ & 54 & $\begin{array}{l}1.2 \\
(0.055)\end{array}$ \\
\hline \multirow{2}{*}{$\begin{array}{l}\text { Height of } \\
\text { tallest tiller } \\
\text { in } \mathrm{cm}\end{array}$} & SFRFS 1979 & 7 & $\begin{array}{l}61.0 \\
(7.620)\end{array}$ & 14 & $\begin{array}{l}60.8 \\
(6.734)\end{array}$ & 3 & $\begin{array}{l}94 \cdot 6 \\
(13 \cdot 548)\end{array}$ & 14 & $\begin{array}{l}90 \cdot 1 \\
(5 \cdot 279)\end{array}$ \\
\hline & Hopland 1980 & 35 & $\begin{array}{l}32 \cdot 3 \\
(2 \cdot 913)\end{array}$ & 52 & $\begin{array}{l}38 \cdot 5 \\
(2 \cdot 428)\end{array}$ & 56 & $\begin{array}{l}42 \cdot 3 \\
(2 \cdot 153)\end{array}$ & 54 & $\begin{array}{l}42 \cdot 0 \\
(2 \cdot 341)\end{array}$ \\
\hline \multirow{2}{*}{$\begin{array}{l}\text { Dry weight of } \\
\text { aerial portion, } \\
\text { in } \mathrm{g}\end{array}$} & SFRFS 1979 & 7 & $\begin{array}{c}0.373 \\
(0.114)\end{array}$ & 12 & $\begin{array}{c}0.586 \\
(0.146)\end{array}$ & 3 & $\begin{array}{c}2.293 \\
(0.273)\end{array}$ & 15 & $\begin{array}{c}2.145 \\
(0.355)\end{array}$ \\
\hline & Hopland 1980 & 35 & $\begin{array}{c}0.115 \\
(0.035)\end{array}$ & 52 & $\begin{array}{c}0.131 \\
(0.018)\end{array}$ & 55 & $\begin{array}{c}0.145 \\
(0.021)\end{array}$ & 53 & $\begin{array}{c}0.196 \\
(0.034)\end{array}$ \\
\hline \multirow[t]{2}{*}{ Number of seeds } & SFRFS 1979 & 7 & $\begin{array}{l}34 \cdot 6 \\
(11 \cdot 125)\end{array}$ & 13 & $\begin{array}{l}45 \cdot 1 \\
(10 \cdot 195)\end{array}$ & 3 & $\begin{array}{l}110 \cdot 7 \\
(16 \cdot 826)\end{array}$ & 15 & $\begin{array}{l}109 \cdot 1 \\
(15 \cdot 388)\end{array}$ \\
\hline & Hopland 1980 & 35 & $\begin{array}{l}12 \cdot 5 \\
(2 \cdot 542)\end{array}$ & 53 & $\begin{array}{l}12 \cdot 9 \\
(1.621)\end{array}$ & 56 & $\begin{array}{c}9 \cdot 5 \\
(1 \cdot 127)\end{array}$ & 53 & $\begin{array}{l}10.4 \\
(1.029)\end{array}$ \\
\hline \multirow{2}{*}{$\begin{array}{c}\text { Flowering date } \\
\text { (days after } \\
\text { March 19) }\end{array}$} & SFRFS 1979 & 13 & $\begin{array}{l}48 \cdot 7 \\
(1 \cdot 303)\end{array}$ & 23 & $\begin{array}{l}50.4 \\
(1.031)\end{array}$ & 5 & $\begin{array}{l}43 \cdot 0 \\
(2 \cdot 074)\end{array}$ & 9 & $\begin{array}{l}44.8 \\
(0.830)\end{array}$ \\
\hline & Hopland 1980 & 39 & $\begin{array}{l}30.5 \\
(0.628)\end{array}$ & 56 & $\begin{array}{l}32 \cdot 2 \\
(0.870)\end{array}$ & 57 & $\begin{array}{l}3 ? .9 \\
(0.691)\end{array}$ & 54 & $\begin{array}{l}32 \cdot 2 \\
(0.621)\end{array}$ \\
\hline
\end{tabular}

* SFRFS 1979 common garden, DL; Hopland 1980 common garden, FR.

† Standard errors of the means are given in parentheses below the means.

mature plants. In every instance, the HP means were significantly greater than those of the two xeric-genotype populations. Seedling means from the same floret in the two xeric populations tended to be the same.

The expectations for the mature-plant results-based on the seedling study and on other studies already mentioned-were that (1) means of separate upper- and lower-floret samples from the same population would not be significantly different; (2) HP means for quantitative characters would be significantly greater than those of the xeric-population means; and (3) comparisons of the two xeric populations with HP in the two gardens would be consistent. The data were consistent with these expectations.

California meadow mice (Microtus californicus) ate many of the experimental plants in the SFRFS 1979 garden, which accounts for the small sample sizes listed in table 4 . In spite of this, the expected pattern appears clearly in the results (table 5).

The 1979-1980 year was a wet one, producing high germination and seedling establishment at the Hopland site. Within- and between-species competition limited plant growth in the Hopland 1980 garden, eliminating 


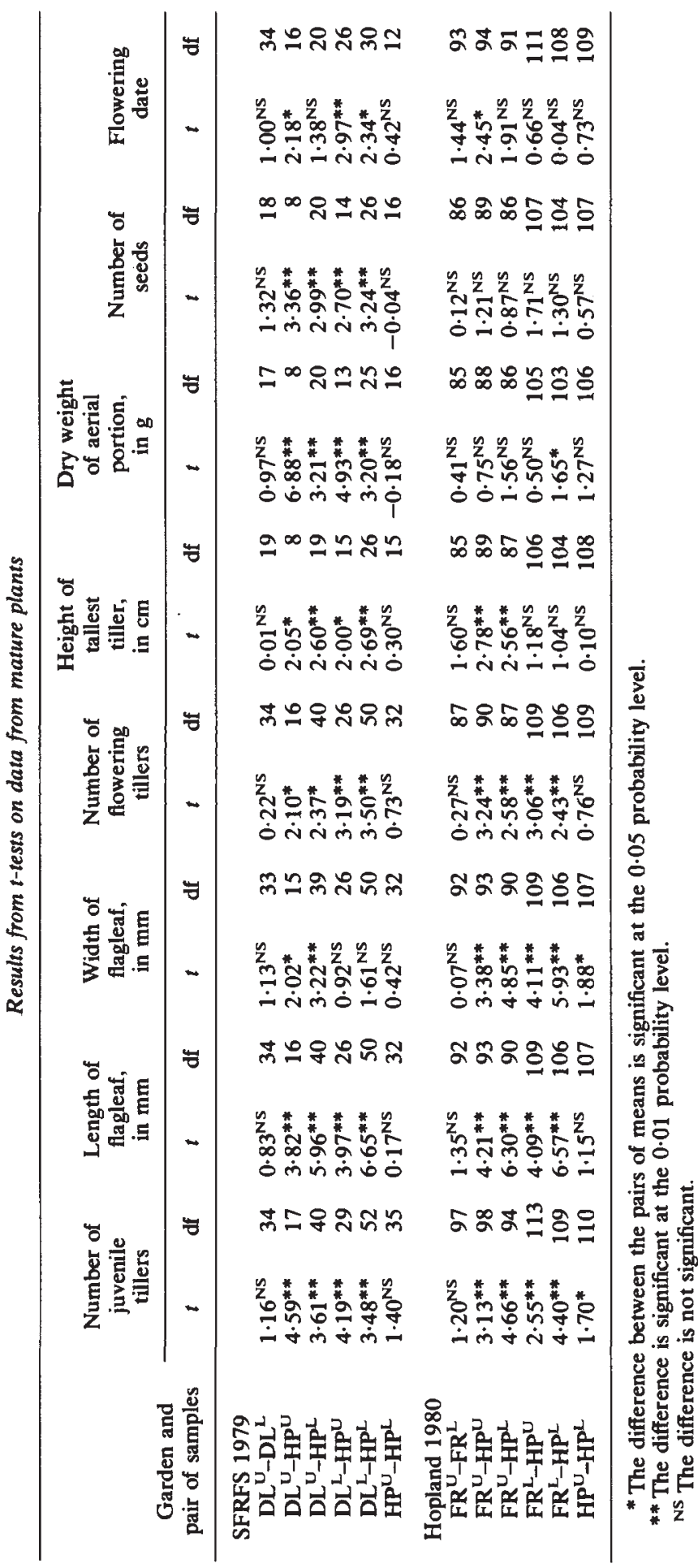


some of the between-population differences and reducing others, in comparison with the data for the previous year (see means in table 4). Overall, the plants were at the very lower limit of size for the species. Betweenpopulation differences in dry weight and number of seeds were not significant. But even at this extreme, between-population differences in flagleaf dimensions and tiller numbers, although small, were significant.

Flowering-date $t$-tests, unlike all of the others on common-garden data, were evaluated as two-tailed tests as there was no source for the formulation of alternative hypotheses for one-tailed tests. The important flowering-date results are the findings of no significant differences between any of the pairs of upper- and lower-floret samples from the same population.

Other studies already mentioned have produced data on quantitative characters of mature plants in California $A$. barbata populations. The present study shows that seeds and very young seedlings of the xeric genotype are smaller than those of California populations of $A$. barbata characterised by other genotypes.

This study was addressed to the question of whether seed size has any effect upon quantitative characters in the latter half of the life cycle. There is clearly no continuing effect deriving from the size differences associated with floret position. Where larger seeds from one population produced larger mature plants than smaller seeds from another population, it may be assumed that this happened not because the plants from the larger seeds "had a better start", but because they have different genotypes at many loci. The mature-plant data, from plants grown under natural conditions, show that only genotype and external environment-and not differing maternal contributions of seed foodstores-contribute to the expression of quantitative characters during the latter half of the life cycle of $A$. barbata plants in nature.

Acknowledgments. I thank M. M. Martin for assistance with the design and execution of the experimental procedures and R. W. Allard, A. Hakim-Elahi, and O. Muona for useful criticism of the manuscript. This work was supported in part by NIH National Research Award 5-T32-GM07467.

\section{REFERENCES}

ALlARD, R. W., BABBEL, G. R., CLEGG, M. T. AND KAHLER, A. L. 1972. Evidence for coadaptation in Avena barbata. Proc. Nat. Acad. Sci. USA, 69, 3043-3048.

CAVERS, P. B. AND HARPER, J. L. 1966. Germination polymorphism in Rumex crispus and Rumex obtusifolius. J. Ecol., 54, 367-382.

CleGg, M. T. AND ALlARD, R. W. 1972. Patterns of genetic differentiation in the slender wild oat. Proc. Nat. Acad. Sci. USA, 69, 1820-1824.

HAMRICK,J. L. AND ALLARD, R. W. 1972. Microgeographical variation in allozyme frequencies in Avena barbata. Proc. Nat. Acad. Sci. USA, 69, 2100-2104.

HAMRICK, J. L. AND ALLARD, R. W. 1975. Correlations between quantitative characters and enzyme genotypes in Avena barbata. Evolution, 29, 438-442.

HAMRICK, J. L. AND HOLDEN, L. R, 1979. Influence of microhabitat heterogeneity on gene frequency distribution and gametic phase disequilibrium in Avena barbata. Evolution, 33, 521-533.

HARKNESS, R. D. 1965. The effect of seed size on early growth of diploid and tetraploid Italian ryegrass. J. Brit. Grassl. Soc., 20, 190-193.

HUTCHINSON, E. S. AND ALLARD, R. W. Genetic markers and ecotypic differentiation in Avena barbata. In preparation.

KNEEBONE, W. R. AND CREMER, C. L. 1955. The relationship of seed size to seedling vigor in some native grass species. Agron. J., 47, 472-477. 